\title{
とらもろこしの雌穂分化過程についで
}

\author{
浦野㤵司・双口進·畐中悌 \\ （長野罢農業試験場桔梗ア原分場）
}

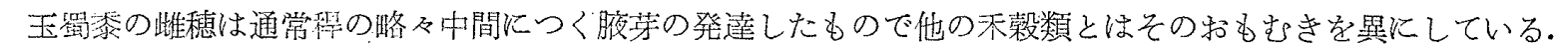
そして着崔穂愔置は倒伏を密接な関係がありまた施肥時期の決定の上からもこの分化過程を知る事は重要な事で ある。

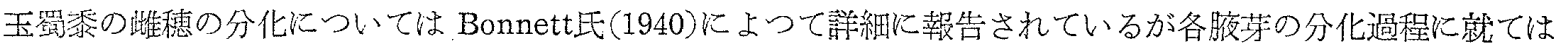
記述されていないし又同氏の取技つた材料はSweet Cornに就てであり我々が実際に栽培しているhybridCornに 就ては研究されていない. 篗者等は hybrid Corn の代表品種である長艾 202 号について雌穗の分化過程を調查 したのでその結果を報告する。

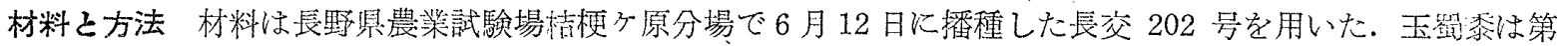
一節から各節位每に腋茅が順次発生する性質があるので展開葉 3 枚の時から展開葉 1 枚增加する毎に調査した。

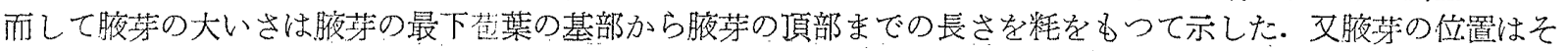

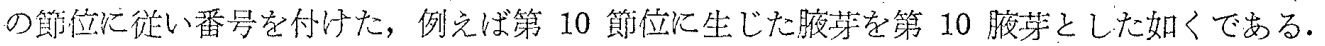

実験結果 第 1 表に示す通り6月20日の調查では 8 節以上の腋芽は未だ分化していない: 6 月23日には第 8 ， 9，10，11 節位の葉腋がわずかに膨及腋芽始原体の分化前の状態にあつた。 6 月27日には第 14 節までの各葉腋 飞腋芽が分化劣始め，8，9，10 節位の腋芽は造葉始原体の分化が始まつていた。而して腋芽の大いさは下節の

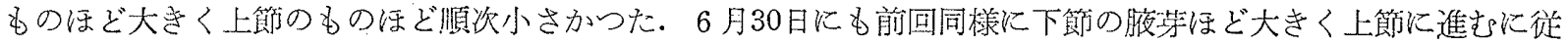
い腋芽汭小さいが既に全腋芽に苍葉が分化していた。7月4日には上下いずれの腋芽も汪添同大で第 13 ，14腋 芽は $0.35 ， 0.28$ であるが他は 0.4 秏であつた又各腋芽の生長点は多くの苞葉始原体突起に囲まれていた。然 かるに7月.7日の調查では第 13 腋芽が腋芸中最大のものとなり７月9日には最上位（第 14 ）腋芽が腋芽中 最大のものとなつた．然して第 $12 ， 13 ， 14$ 腋芽に小䅼始原体である側乫起が分化した. 図 I.Jに示すよ5に 此穗の分化は腹芽の生長点が伸長し小穂始原体が分化する事である。この小穂の分化する時期が䧳穂では栄養生 長から生殖生長への転換期と推察される、㕛この時期は腋芽の肥大生長が急速であるため環境に比較的支配され やすい時期である。7月12日の調查では上位，特に最上位（第 14）の雌穂は急速澄育するが下位の腋芽の肥 大快緩漫となり発育停止状態に近い。第 12,13 腋芽の肥大程度は最上位腋芽にくらべると明らか飞劣つてい る.この垻落は急速に伸長し始める.7月18日の調盗で新しい形態的変化は小穂始原体が不平等な 2 塊になる事

Table. I diffrerentiation of corn at various growth-stage.

\begin{tabular}{|c|c|c|c|c|c|c|c|c|c|c|}
\hline Sampling date & & June 20 & 23 & 27 & 30 & July 4 & 7 & 9 & 12 & 18 \\
\hline \multicolumn{2}{|c|}{ Number of leaf attained full length } & 3 & 3 & 4 & 5 & 6 & 7 & 8 & 9 & 10 \\
\hline \multicolumn{2}{|c|}{ Height of plant .... } & 36 & 38 & 47 & 64 & 78 & 83 & 87 & 115 & 141 \\
\hline \multirow{2}{*}{\multicolumn{2}{|c|}{ Differentiation of tassel }} & 0.03 & 0.04 & 0.05 & 0.15 & 0.33 & 0.50 & 1.80 & 8.00 & 14.00 \\
\hline & & A & B & C & $\mathrm{D}$ & $\mathrm{E}$ & $\mathrm{F}$ & G & $\mathrm{H}$ & I \\
\hline \multirow{7}{*}{$\begin{array}{l}\text { Differentiation } \\
\text { of ear }\end{array}$} & Node No. 1.4 & & & 0.08 & 0.10 & 0.28 & 0.76 & 1,87 & 2.56 & 3.48 \\
\hline & 13 & & & 0.08 & 0.12 & 0.35 & 0.84 & 1.45 & 2.10 & 2.65 \\
\hline & 12 & & & 0.09 & 0.15 & 0.40 & 0.80 & 1.20 & 1.50 & 1.80 \\
\hline & 11 & & $\mathrm{~J}$ & 0.14 & 0.20 & 0.41 & 0.60 & 0.75 & 0.90 & 1.26 \\
\hline & $10^{\circ}$ & & " & 0.20 & 0.26 & 0.41 & 0.50 & 0.55 & 0.65 & 0.74 \\
\hline & 9 & & " & 0.25 & 0.33 & 0.41 & 0.45 & 0.50 & 0.52 & 0.53 \\
\hline & 8 & & $"$ & 0.28 & 0.38 & 0.40 & 0.41 & .0 .42 & 0.43 & 0.43 \\
\hline
\end{tabular}

Nates : bold letters indicates differentiation of the spikelet. A) the growing point just before tassel differentiation. B) beginning of the differentiation of the tassel. C) more advanced stage of tassel initial differentiation. D) differentiation of the branches of the tassel. E) elongation of the branches of the tassel. F) beginning of the differentiation of the spikelet initials on the central axis of the tassel. G) differentiation of empty glume. H) the differentiation of the anther initial. I) meiosis stage. J) just before ear differentiation.

* 昭和 31 年 10 月 6 日 第 112 回講演会汇於て発表 日本作物学会紀事 第 25 号 第 3 巻（昭和 32 年 4 月） 
である(P図参照)、玉蜀愁の 1 雌穂中ではその下部では小穗が分化しているにもかかわらず，その頂点は伸長

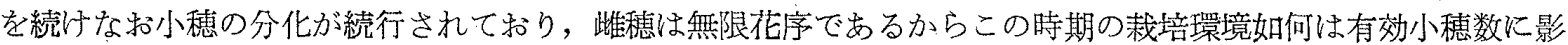
響を及济するのである。然し雌穗の䊀列数は雌穗の特性として決定される。

考 察 本実験に使用した長交 202 号では全葉 16 枚の時最上腋芽が分化し始好た。しかし葉数は花序の正し い発生段階を示するのではなく同一葉数であつても生育状態や其の他の原因によつて腋芽の発育程度に羑がある あのである. 又雄穂は 6 月 20 日に既炕分化して拈り分枝群の出来るのは全葉 19 枚の時であり，これより以後の 荎長の増加はるつぱら節間伸長に上る事が誌められた。㬸芽は最初は基部から上部へ々順次荎の発青に応じて分 化するが，中途（播種後 42 日目）から上部の腋芽が急速に分化が進み，雌穗始原体は茎の上部の腋芽に出現し，

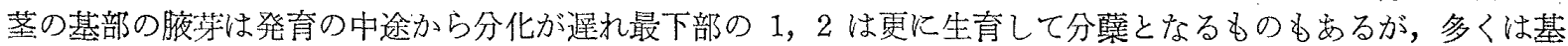

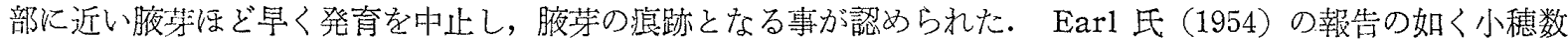
の決定する時期（当実験材料では播種後 47〜 53 日）飞充分肥効のめる様に施肥を行ら事及び小穂の発育が盛ん になる様に特に栽培環境に注意する必要がある..Alexander 氏 (1952) は各節の雌穂の粒列数は多くは最高雌穂 が最も多いと報告しているし簐者等の観察でもほとんど最高位雌穗が最大であつた。本調查恃長交 202 号につい て行なつた結果ではあるが，他の品種に於ても時期的差違はあるとしても雌穂発育過程於て上下の雌穂の間に 分化の転撸は同㥞に起るものと推察されるが，この転換の起る原因は今後の研究に待つるのがある.
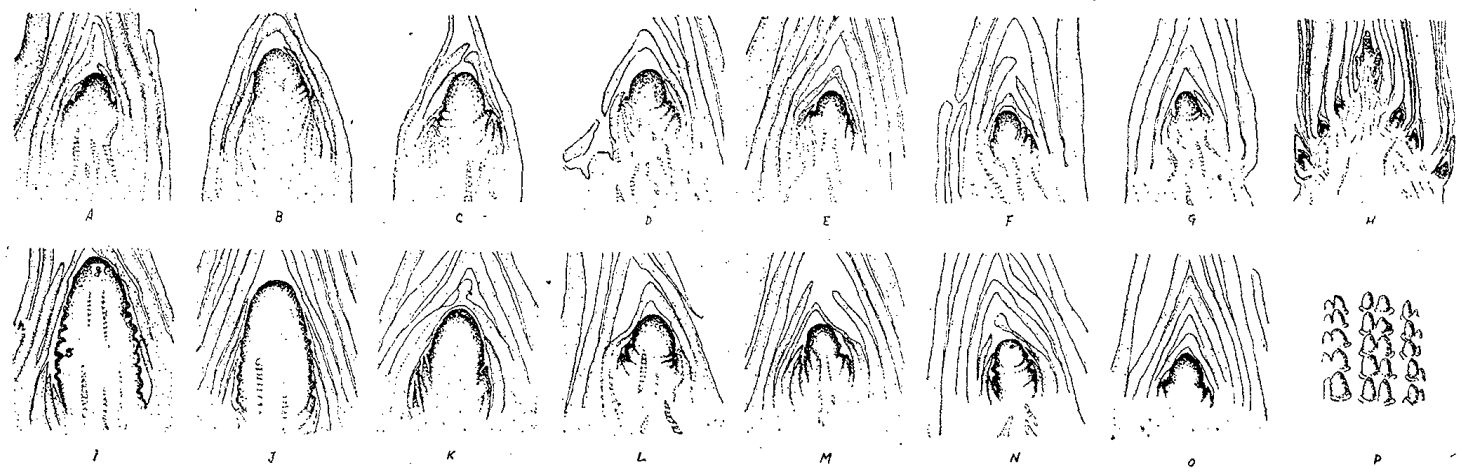

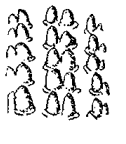

Fig. I differentiation of axillary shoot in each axil

Note : A-G axillary shoots in $14 \sim 7$ node on July $7, \mathrm{H}$ axillary shoots in $14 \sim 8$ node on June 30 , $\mathrm{I} \sim \mathrm{O}$ axillary shoots in $14 \sim 7$ node on July $9, \mathrm{P}$ beginning of spikelet differentiation by an unequal division of the branch initiales. $\mathrm{h}:$ husk, $\mathrm{s}:$ spikelet initial, $\mathrm{g}:$ growing point.

交 献 1) Abbe, E.C. and B. O. Phinney, Amer. Jour. Bot. 38, 737-743 (1951). 2) Abbe, E. C., B. D., Phinney and D.F. Bare, Amer. Jour. Bot. 38, 744-751 (1951). 3) Alexander, D. E., Agron, Jour. 44, 430-433 (1952). 4) Bonnett, O. T., Jour. Agr. Res. 60, 25-38 (1940). 5) Ear1, R. L., Agron. Jour. 46，502-506 (1954)。6）稻村宏，鈴木幸三郎，野中舜二 農業改良技術資材 62，(1955) 7) Sircar, S. M. and S. D. Ien, Bot. Gaz. 436-448 (1953)

\section{Studies on the Ear Differentiation of Corn Plant}

Keishi Urano, Susumu Sakaguchr and Yasushi Tanaka

(Kikyōgahara Branch, Nagano Agricultural Experiment station)

\section{Résumé}

Differentiation of ear may vary more or less with the environmental condition. On chōkō-No. 202, following facts were ascertained. 1) The shoot of the corn plant passes through two stages in its differentiation sequence. During the first stage, axillary shoots became larger in succession from the apex to the base of the stem. During the second stage, the order in size changes, so that the topmost shoot is the largest and shoots become smaller at the base than the top of the plant. On 42 days after planting, its change was found. 2) In the early stage of stem development, a shoot is produced in the axil of each leaf but at a later stage of development, axillary shoots are no longer produced. The cessation of axillary shoot development seems to be associated with tho elongation of the internodes of the stem and the development of the tassel. In early stage of shoot development, the axillary shoots differentiate at the lower node but in later the topmost shoot is the largest and these shoots formed at the base of the stem may remain nonfunctional or deveiop in to sackers. 3) On 44 dass after planting, spikelet initial differentiate. When the growing point of the axillary shoot elongates and the spikelet on the central axis was differentiates, we recognized ear dlifferentiation. 4) It is considered important in corn culture to acertain the period of ear dfferentiatiation and the sige of each axillary shoot. 